\title{
Genetic Variability, Heritability and Genetic Advance for Yield and its Contributing Traits in Wheat (Triticum aestivum L.) Genotypes
}

\author{
Anurag Kumar*, Lokendra Singh, Kanhaiya Lal and Ashvani Kumar \\ Department of Genetics and Plant Breeding, Chandra Shekhar Azad University of Agriculture \\ \& Technology, Kanpur - 208002 (U.P.), India \\ *Corresponding author
}

\begin{tabular}{l} 
Ke y w o r d s \\
Genetic Variability, \\
Heritability, \\
Wheat (Triticum \\
aestivum L.) \\
\hline Article Info \\
$\begin{array}{l}\text { Accepted: } \\
18 \text { March } 2021 \\
\text { Available Online: } \\
10 \text { April } 2021\end{array}$ \\
\hline
\end{tabular}

A B S T R A C T

The present study was carried out to evaluate fifty wheat genotypes of different ecogeographic origin. Data on eight quantitative characters viz., Plant height, reproductive tillers/plant, length of spike, spikelets/spike, days to maturity, grains/spike, test weight and grain yield/plant were recorded. Analysis of variance (ANOVA) revealed significant differences among the genotypes for almost all the traits under study. The genotypes showed moderate to high level of genotypic coefficients of variance (GCV) and phenotypic coefficients of variance (PCV). In general, phenotypic coefficient of variance was found to be higher than their genotypic coefficient of variance but difference was quite meager, indicating negligible environmental influence on the expression of the characters. Higher estimate of GCV (15.55) was recorded for length of spike followed by grain yield per plant (14.91). The higher value of heritability was observed for test weight (99.18) followed by plant height (96.31), grains/spike (92.01), length of spike (91.34), reproductive tillers/plant (90.89), grain yield/plant (90.40), spikelets/spike (88.02) and lowest value of heritability was observed for days to maturity (79.56). The maximum value of genetic advance as percent of mean was recorded for length of spike (30.62) followed by grain yield/plant (29.20), reproductive tillers/plant (21.10) and plant height (20.74). The characters such as length of spike, reproductive tillers per plant, grain yield per plant and plant height, showing high heritability and high genetic advance would be more effective selection parameters, since they showed very less environmental influence.

\section{Introduction}

Wheat (Triticum aestivum L.), belongs to Gramineae (Poaceae) family and genus Triticum, is the major world's cereal crop. It has been described as the 'King of Cereals' because it occupies large acreage, high productivity and prominent position for food grain basket. It occupies a unique position in human life as it is the major source of food and energy with a large number of end use products like chapatti, bread, biscuits, pasta and is also a good source of fodder for animals. Wheat is grown on 215.9 million 
hectares throughout the world, which produces 725.91 million tons of grain (Foreign Agricultural Services, USDA, 2015). It provides, on an average, one fifth of total calorific input to the world population. Wheat in India is grown over an area of 29.86 million ha producing 95.85 million tonnes (FAO, 2008). With the enormous increase in the population, the demand for wheat is also increased. Therefore it becomes essential to identify such genotypes that are able to provide maximum yield under various ecological conditions. To fulfill such type of requirements, calculation of genetic variability in the existing genotypes is much more essential, since genetic variability is a prerequisite for any breeding programme. Heritability estimates are useful in predicting the transmission of characters from the parents to their offspring that enabled us to select elite genotypes from the mixed parental population or segregating populations, while estimation of genetic advance help in understanding the type of gene action involved in the expression of various polygenic characters. Therefore the present investigation carried with the aim to estimate genetic variability, heritability and genetic advance of different yield contributing traits in wheat genotypes.

\section{Materials and Methods}

The present investigation was carried out during Rabi 2016-17 at crop research farm of Chandra Shekhar Azad University of Agriculture and Technology, Kanpur (U.P.) using Randomized Complete Block Design with three replications to work out the status of genetic variability, association of different seed yield traits and direct \& indirect effects of these traits on seed yield in fifty genotypes/lines of wheat. These lines were taken from the germplasm maintained, in the Genetics and Plant breeding department of the university. Each genotype was sown in two lines of $5.0 \mathrm{~m}$ long with $23 \mathrm{~cm}$ wide plot and $5 \mathrm{~cm}$ plant to plant distance. The observations were recorded on five randomly taken plants for eight quantitative characters viz., Plant height $(\mathrm{cm})$, Number of reproductive tillers per plant, Length of spike $(\mathrm{cm})$, Number of spikelets per spike, Days to maturity, Number of grains per spike, Test weight (g), Grain yield per plant $(\mathrm{g})$. Crop research farm is situated between $26.46070 \mathrm{~N}$ latitude, $80.33340 \mathrm{E}$ longitudes and at an altitude of $126 \mathrm{~m}$ above the mean sea level, near company bag, Kanpur. Kanpur district has humid subtropical climate and low temperature in winter season and high temperature in summer season. The experimental data collected in respect of eight characters on 50 wheat genotypes were compiled by taking the mean values of selected plants in each plot and subjected for Analysis of variance, Estimation of heritability (Burton and De vane (1953)) and genetic advance (Johnson et al., (1955).

\section{Results and Discussion}

\section{Variability among different genotypes for various quantitative characters}

Magnitude and nature of variability present in a population is a pre- requisite for any crop improvement programme. Variation in population is a result of its genotype, environment and genotype $\mathrm{x}$ environment interactions. Only heritable component of variation is of prime importance from breeding point of view. So it is necessary to divide the total variability into its heritable and non-heritable component of variation. ANOVA for eight characters in wheat is given in table 1 and Phenotypic and genotypic coefficients of variation for 8 characters in wheat in table 2 .

In present study maximum phenotypic and genotypic coefficient of variation was 
observed for length of spike (16.28) and (15.55), respectively. It indicated that simple selection for length of spike may be more advantageous as compared to other yield contributing characters under study. However, magnitude of others viz., grain yield per plant exhibited phenotypic coefficient of variation (15.68) and genotypic coefficient of variation (14.91), productive tillers per plant phenotypic coefficient of variation (11.27) and genotypic coefficient of variation (10.74), plant height phenotypic coefficient of variation (10.45) and genotypic coefficient of variation (10.26), grains per spikes phenotypic coefficient of variation (8.68) and genotypic coefficient of variation (8.33), spikelets per spike showed phenotypic coefficient of variation (7.95) and genotypic coefficient of variation (7.46), test weight phenotypic coefficient of variation (6.57) and genotypic coefficient of variation (6.54), days to maturity phenotypic coefficient of variation (2.63) and genotypic coefficient of variation (2.35) were found in diversity order respectively. Genotypic coefficient of variation is more important than that of phenotypic coefficient of variation because higher amount of genotypic variation helps in formulation of effective breeding program for crop improvement. The characters such as length of spike, grain yield/plant, productive tillers/plant, plant height, grains/spike, spikelets/spike, test weight, days to maturity exhibited low environmental influence. This indicated availability of more chances of improvement through selection breeding programme. This result is agreement to the findings of Singh and Sherma (2007), Lal et al., (2009), Kallim Ullah et al., (2012), Kumar et al., (2013), Dutamo et al., (2015) and Ali et al., (2016).

\section{Heritability and genetic advance}

The effectiveness of selection for any characters depends not only on the amount of variability for a character present in the population but also type of inheritance from parent to their off-springs. The heritable variation can be obtained through heritability and genetic advance of different characters.

From breeding point of view, only heritable component of the total variation is great importance for crop improvement. This revealed the imperative need of partitioning the overall variability into heritable and non heritable component with the help of heritability and genetic advance estimates.

The heritability estimates along with genetic advance gives more reliable information than the heritability alone. Heritability estimate does not provide ample evidence regarding the amount of genetic progress, which could be possible through selection. If heritability is mainly due to non-additive gene effect, the value of genetic gain would be low but if heritability is mainly due to additive gene effect the value of genetic gain would be high. Heritability (Broad sense), genetic advance and genetic advance over mean for 8 characters in wheat are given in table 3 and figure $3 \mathrm{~A}$.

The high value of heritability was observed for almost all the characters studied. The higher value of heritability was observed for test weight (99.18), followed by plant height (96.31), grains/spike (92.01), length of spike (91.34), reproductive tillers/plant (90.89), grain yield/plant (90.40), spikelets/spike (88.08) and days to maturity (79.56).

The higher value of genetic advance was observed for plant height (16.18) followed by grains/spike (6.84), days to maturity (5.15), test weight (4.93), grain yield/plant (3.47), length of spike (2.88), and spikelets/spike (2.57). The lowest value of genetic advance was observed for reproductive tillers/plant (1.67). 
The highest value of genetic advance in percent of mean was recorded for length of spike (30.62) followed by grain yield/plant (29.20), reproductive tillers/plant (21.09), plant height (20.74) and grains/spike (16.46), spikelets/spike (14.41) and test weight (13.42).The lowest value for genetic advance in percent of mean was recorded for days to maturity (4.31).

Table.1 ANOVA for eight characters in wheat

\begin{tabular}{|l|l|l|l|l|l|l|l|l|l|}
\hline $\begin{array}{l}\text { Source of } \\
\text { variation }\end{array}$ & $\begin{array}{l}\text { Degre } \\
\text { e of } \\
\text { freed } \\
\text { om }\end{array}$ & $\begin{array}{c}\text { Plant } \\
\text { height } \\
\text { (cm) }\end{array}$ & $\begin{array}{c}\text { Reproducti } \\
\text { ve tillers/ } \\
\text { plant } \\
\text { (cm) }\end{array}$ & $\begin{array}{c}\text { Length of } \\
\text { spike } \mathbf{( c m )}\end{array}$ & $\begin{array}{l}\text { Spikelets } \\
\text { /spike }\end{array}$ & $\begin{array}{l}\text { Days to } \\
\text { maturity }\end{array}$ & $\begin{array}{c}\text { Grains } \\
\text { /spike }\end{array}$ & $\begin{array}{c}\text { Test } \\
\text { weigh } \\
\mathbf{t}(\mathbf{g m})\end{array}$ & $\begin{array}{c}\text { Grain } \\
\text { yield/ } \\
\text { plant } \\
\text { (gm) }\end{array}$ \\
\hline Replication & 2 & 2.51 & 0.000 & 0.111 & 0.380 & 0.607 & 0.541 & 0.0450 & 0.128 \\
\hline Treatment & 49 & $194.52^{* *}$ & $2.24^{* *}$ & $6.64^{* *}$ & $5.55^{* *}$ & $25.54^{* *}$ & $37.03^{* *}$ & $17.40^{*}$ & $9.76^{* *}$ \\
\hline Error & 98 & 2.45 & 0.073 & 0.203 & 0.241 & 2.04 & 1.04 & 0.048 & 0.334 \\
\hline \\
\hline
\end{tabular}

Table.2 Phenotypic and genotypic coefficients of variation for 8 characters in wheat

\begin{tabular}{|c|c|c|c|}
\hline S. No. & Characters & PCV & GCV \\
\hline $\mathbf{1}$ & Plant height $(\mathrm{cm})$ & 10.45 & 10.26 \\
\hline $\mathbf{2}$ & Productive tillers/plant & 11.27 & 10.74 \\
\hline $\mathbf{3}$ & Length of spike & 16.28 & 15.55 \\
\hline $\mathbf{4}$ & Spikelets/spike & 7.95 & 7.46 \\
\hline $\mathbf{5}$ & Days to maturity & 2.63 & 2.35 \\
\hline $\mathbf{6}$ & Grains/spike & 8.68 & 8.33 \\
\hline $\mathbf{7}$ & Test weight & 6.57 & 6.54 \\
\hline $\mathbf{8}$ & Grain yield/ plant & 15.68 & 14.91 \\
\hline
\end{tabular}

Table. 3 Heritability (Broad sense), genetic advance and genetic advance over mean for 8 characters in wheat

\begin{tabular}{|c|c|c|c|c|}
\hline S.No. & Characters & Heritability (\%) & $\begin{array}{c}\text { Genetic } \\
\text { advance }\end{array}$ & $\begin{array}{c}\text { Genetic advance in } \\
\text { percent of mean }\end{array}$ \\
\hline $\mathbf{1}$ & Plant height(cm) & 96.31 & 16.18 & 20.74 \\
\hline $\mathbf{2}$ & Reproductive tillers/plant & 90.89 & 1.67 & 21.10 \\
\hline $\mathbf{3}$ & Length of spike & 91.34 & 2.88 & 30.62 \\
\hline $\mathbf{4}$ & Spikelets/spike & 88.02 & 2.57 & 14.41 \\
\hline $\mathbf{5}$ & Days to maturity & 79.56 & 5.15 & 4.31 \\
\hline $\mathbf{6}$ & Grains/ spike & 92.01 & 6.84 & 16.46 \\
\hline $\mathbf{7}$ & Test weight & 99.18 & 4.93 & 13.42 \\
\hline $\mathbf{8}$ & Grain yield/Plant & 90.40 & 3.47 & 29.20 \\
\hline
\end{tabular}




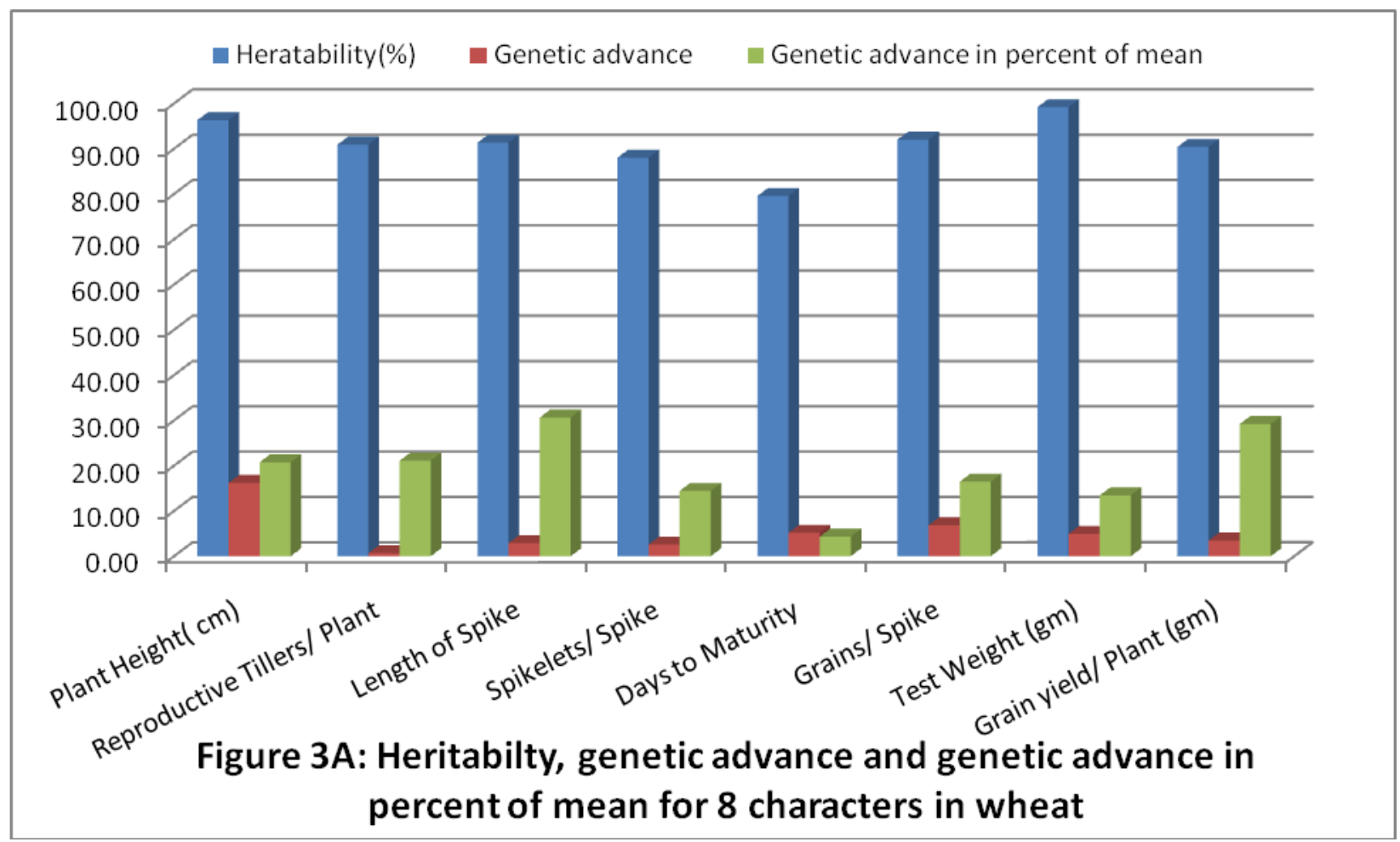

The characters such as test weight, plant height, grains/spike, reproductive tillers/plant, length of spike are quite encouraging. Since these characters have exhibited estimates of high heritability, which indicated that these characters are least influenced by environment and showed least genotype $\mathrm{x}$ environment interaction.

These results are in agreement to the findings of Kumar et al., (2013), Hussain et al., (2013), Singh et al., (2017) and Kumar et al., (2014).

\section{References}

Ali T., Bhardwaj, D. N., Singh, L. (2016). Environment and Ecology 35(3) 20812083.

Burton, G. W, de Vane, E. W. (1953). Estimating heritability in tall fescue (Festuca arundinacea) from replicated clonal material. Agron. J., 45:178-181.

Dutamo, D., Sentayehu, A., Firdisa, E. and
Gezahegn, F. (2015). Genetic Variability in Bread Wheat (Triticum aestivum L.) Journal of Biology, 5(13). 130-145.

FAO Statistical Yearbook 2008, Statistical Division, Food and Agricultural Organization, Rome.

Foreign Agricultural Services, USDA, 2015. Hussain, M. A., Askandar, H. S. and Hassan, Z. A. (2013). Selecting high yielding wheat hybrids from a restricted mating design. Sharad Journal of Agriculture, 29(2) 173-179.

Johnson, H.W., Robinson, H.F. and Comstock, R.E (1955). Estimation of genetic and environmental variability in soybean. Agron. J., 47: 314-318.

Kallim, U. K., Irfaq, M. and Rahman, H. U. (2012). Genetic Variability, correlation and diversity studies in bread wheat (Triticum. aestivum L.). Journal of Animal and Plant Sciences, 22(2): 330333.

Kumar, N., Markar, S. and Kumar, V. (2013). 
Studies on heritability and genetic advance estimates in timely sown bread wheat (Triticum aestivum L.). Biosci. Disc., 5(1):64-69.

Kumar, Y, Lamba, R., Balbir, A. S., Kumar, V. (2014). Genetic variability, correlation and Path analysis in wheat varieties under late sown condition. Annals of Agri Bio Research,19 (4) 724727.

Lal, B. K., Ruchig, M. and Upadhyay, A. (2009). Genetic variability, diversity and association of quantitative traits with grain yield in bread wheat
(Triticum aestivum L.). Asian Journal of Agricultural Sciences, 1 (1): 4-6.

Singh, S.V., Yadav, R. K. and Singh, S. K. (2017). Genetic variability, heritability, genetic advance and correlation studies for yield components and quality parameters in wheat (Triticum aestivum L.). Progressive Research, 12(1): 110114.

Singh, T. and Sharma, R. K. (2007). Genetic variability, character association and path analysis of yield and its component characters in durum wheat. Progressive Agriculture, 7(1/2): 15-18.

\section{How to cite this article:}

Anurag Kumar, Lokendra Singh, Kanhaiya Lal and Ashvani Kumar. 2021. Genetic Variability, Heritability and Genetic Advance for Yield and its Contributing Traits in Wheat (Triticum aestivum L.) Genotypes. Int.J.Curr.Microbiol.App.Sci. 10(04): 794-799. doi: https://doi.org/10.20546/ijcmas.2021.1004.082 